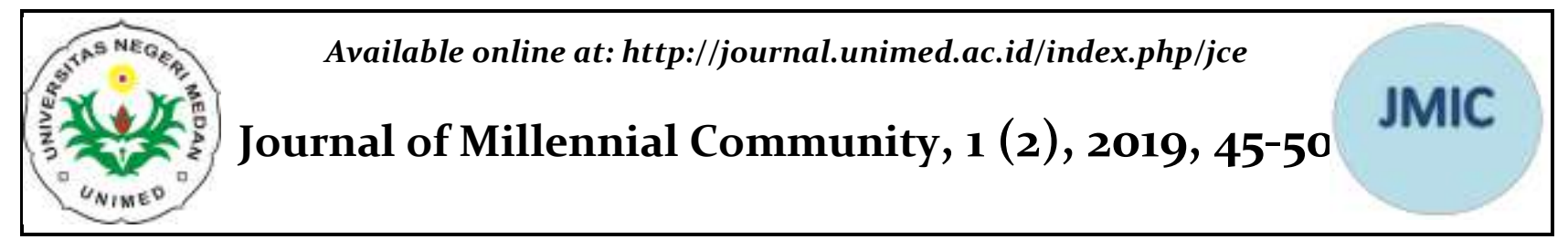

\title{
Perbedaan Motivasi Belajar Antara Mahasiswa Yang Indekos Dengan Mahasiswa Yang tinggal Bersama Orang Tua
}

\author{
Abraham Lincol Siahaan', Sudirman ${ }^{2}$ \\ ${ }^{1}$ Dinas Sosial Kabupaten Langkat, ${ }^{2}$ Universitas Negeri Medan \\ abrahamlincolsi@ugmail.com
}

\begin{abstract}
Abstrak
Masalah dalam penelitian ini adalah Adakah perbedaan motivasi belajar antara mahasiswa yang indekos dengan mahasiswa yang tinggal bersama orang tua. Penelitian ini bertujuan untuk mengetahui perbedaan motivasi belajar antara mahasiswa yang indekos dengan mahasiswa yang tinggal bersama orang tua. Penelitian ini merupakan penelitian deskriptif kuantitatif. Teknik pengumpulan data melalui penyebaran angket. Sampel dalam penelitian ini adalah 56 mahasiswa, yang terdiri dari 47 mahasiswa yang indekos dan 9 mahasiswa yang tinggal bersama orang tua. Teknik analisa data digunakan dengan mencari perbedaan dengan uji t. Hasil penelitian menunjukan bahwa adanya perbedaan motivasi belajar antara mahasiswa yang indekos dengan mahasiswa yang tinggal bersama orang tua. Nilai motivasi belajar untuk mahasiswa yang indekos adalah 2,85, sedangkan nilai motivasi belajar untuk mahaiswa yang tinggal bersama orang tua lebih tinggi yaitu 2,94. Tingkat signifikansi perbedaan didapat sebesar o,416 yang dikategorikan agak rendah.
\end{abstract}

Kata Kunci: motivasi belajar, mahasiswa, indekos, orang tua

\section{The Learning Motivation Difference Between Students Who Live In Boarding House And Students Who Live With Parents}

\begin{abstract}
The problem in this study was there are differences in learning motivation between students who are boarding and students who live with parents. This study aims to determine differences in learning motivation between students who are boarding and students who live with parents. This research is quantitative descriptive. Data collection techniques through questionnaires. The sample in this study was 56 students, consisting of 47 students who boarded and 9 students who lived with parents. Data analysis technique is used by finding differences with the $\mathrm{t}$ test. The results showed that there were differences in learning motivation between boarding house students and students who lived with parents. The value of learning motivation for boarding house students is 2.85 , while the value of learning motivation for students living with parents is higher at 2.94. The significance level of the difference was 0.416 which was categorized rather low.
\end{abstract}

Keywords: learning motivation, students, boarding house, parents

\section{PENDAHULUAN}

Pengetahuan memiliki peran penting dalam peradaban manusia. Peningkatan kualitas sumber daya manusia sudah merupakan suatu keharusan bagi bangsa Indonesia yang menuntut 
kesiapan setiap masyarakatnya untuk memiliki pengetahuan dan keterampilan agar dapat bersaing secara bebas. Saat ini hanya bangsabangsa yang berkualitas tinggi yang mampu bersaing atau berkompetisi di pasar bebas. Dalam hubungannya dengan budaya kompetisi tersebut, bidang pendidikan memegang peranan yang sangat penting dan strategis karena merupakan salah satu wahana untuk menciptakan kualitas sumber daya manusia.

Pendidikan merupakan proses pembelajaran bagi individu untuk mencapai pengetahuan dan pemahaman yang lebih tinggi mengenai obyekobyek tertentu dan spesifik. Pengetahuan tersebut diperoleh secara formal maupun nonformal yang berakibat individu mempunyai pola pikir dan perilaku sesuai dengan pendidikan yang telah diperolehnya. Pendidikan yang telah diperoleh akan menghasilkan bakat dan kemampuan yang dapat dipengaruhi oleh kebiasaan seseorang. Dengan kebiasaan yang baik, maka seseorang dapat membantu dirinya sendiri dan orang lain untuk mencapai tujuan yang telah ditetapkan.

Untuk mempeoleh kebiasaan yang baik perlu adanya proses beajar. Belajar lebih banyak dilandasi oleh karena adanya motivasi diri dalam menuntut ilmu atau belajar, karena motivasi berperan sangat penting dalam membangun prestasi dalam belajar. Menurut Slameto (2010: 58) “ motivasi tiap orang untuk belajar itu berbeda-beda. Motivasi sudah ada pada saat seseorang akan melakukan sesuatu, namun banyak yang tidak menyadarinya". Oleh karena itu, perlu kita mengetahui apa sebenarnya motivasi belajar yang ada pada diri kita sendiri serta metode dalam belajar yang harus kita terapkan. Seseorang belajar karena didorong oleh kekuatan mentalnya. Kekuatan mental itu berupa keinginan, perhatian, kemauan, atau cita-cita. Kekuatan mental tersebut dapat tergolong rendah atau tinggi.

Seorang mahasiswa yang mulai melangkahkan kakinya masuk ruang kuliah, biasanya disertai dengan semangat belajar yang tinggi. Ia mempunyai cita-cita ingin berhasil dengan gemilang dan dapat menyelesaikan studinya dengan cepat. Ia merasa berbahagia karena cita-cita menjadi mahasiswa telah tercapai. Tetapi setelah beberapa waktu mengikuti kuliah dengan tekun, maka mulailah terasa bahwa belajar di perguruan tinggi bukanlah pekerjaan yang mudah. Banyak kegagalankegagalan yang dialaminya, sehingga akhirnya banyak mahasiswa yang gagal di tengah jalan. Tidak mampu melanjutkan studinya. Cita-citanya menjadi sarjana tidak tercapai. Faktor yang menyebabkannya, salah satu di antaranya adalah kurangnya motivasi belajar dan kurang dipahaminya metode atau strategi mahasiswa dalam belajar di perguruan tinggi. Belajar di perguruan tinggi adalah suatu pekerjaan yang berat, dan belajar di perguruan tinggi sangat berbeda dengan belajar di sekolah menengah. Tanggung jawab belajar hampir seluruhnya dipercayakan pada para mahasiswa. Pengajar atau dosen hanya memberikan dasar-dasar pengetahuan saja. Oleh karena itu, pada mahasiswa dituntut adanya sikap dan perilaku yang benar dalam belajar. Salah satu hal yang penting ketika belajar di perguruan tinggi adalah perlu adanya motivasi yang tinggi pada diri mahasiswa untuk belajar.

Belajar di perguruan tinggi
merupakan kegiatan untuk
mendapatkan pengetahuan,
pemahaman tentang suatu hal, atau
penguasaan kecakapan dalam suatu hal
atau bidang hidup tertentu lewat usaha,
pengajaran atau pengalaman.

Ketiadaan atau kekurangan motivasi belajar membuat mahasiswa 
malas untuk belajar, bersikap apatis terhadap bahan pelajaran, dan berat untuk menghadiri kuliah. Orang yang termotivasi belajar, berminat terhadap bahan belajar, bergairah dalam belajar dan melaksanakan tugas-tugas studi, dan membangun sikap dan kebiasaan belajar yang sehat melalui penyusunan jadwal belajar dan melaksanakannya dengan tekun. Oleh karena itu, motivasi belajar itu sangat penting untuk mahasiswa.

Untuk meningkatkan motivasi dalam belajar, kondisi lingkungan sangatlah memegang peranan penting, dapat berupa keadaan alam, lingkungan tempat tinggal, pergaulan sebaya, dan kehidupan kemasyarakatan (Muljono, Pudji. 2010). Sebagai anggota masyarakat maka mahasiswa dapat terpengaruh oleh lingkungan sekitar. Tempat tinggal mahasiswa selama mengikuti perkuliahan baik itu yang tinggal bersama orang tua ataupun yang indekos merupakan tempat mahasiswa tersebut mendapatkan motivasi dari luar untuk mendukung mahasiswa tersebut dalam belajar. Oleh karena itu kondisi lingkungan tempat tinggal yang sehat, kerukunan hidup, pergaulan yang sehat merupakan hal yang perlu untuk diwujudkan. Dengan lingkungan yang aman, tertib, dan indah, maka semangat dan motivasi belajar akan semakin kuat.

Mahasiswa yang indekos dan jauh dari orang tua meruapakan mahasiswa yang telah dipercayakan oleh orang tua mereka untuk memimpin diri mereka masing-masing. Orang tua mereka telah memfasilitasi dan memberi kepercayaan penuh agar anaknya tersebut behasil meraih gelar sarjana, dan kelak dapat membahagiakan orang tua mereka. Tetapi tidak sedikit diantara mahasiswa yang kost tersebut menyianyiakannya. Setelah mahasiswa tersebut kost, mereka tidak bisa memimpin diri mereka sendiri ke arah yang lebih baik.
Sebagai contoh, banyak mahasiswa yang tidurnya hingga larut malam, bukan karena belajar atau mngerjakan tugas, tetapi karena asik cerita-cerita sama teman, sehingga pada pagi harinya sulit untuk bangun dari tidur, dan masuk kuliah pun jadi terlambat, bahkan ada yang sampai tidak mau masuk kuliah lagi karena sudah terlambat. Di ruang kuliah pun mereka menjadi sering mengantuk, sehingga mahasiswa tidak bisa meningkatkan hasil belajar mereka.

Mahasiswa yang tinggal bersama orang tua merupakan mahasiswa yang selama ia kuliah ia tinggal bersama orang tuanya dalam satu rumah. Pengaruh orang tua dalam pembentukan dan perkembangan kepribadian sangatlah besar artinya. Orang tua memiliki tanggung jawab untuk mendidik, mengasuh dan membimbing anak-anaknya untuk mencapai tahapan tertentu yang menghantarkan anak untuk siap dalam kehidupan bermasyarakat. Tetapi sekarang ini banyak orang tua yang tidak bisa membimbing anaknya dengan baik, kebanyakan waktu orang tua hanya diluar rumah, sehingga waktu untuk berkomunikasi dengan anaknya pun sangatlah terbatas. Hal ini menjadikan anak merasa kurang diperhatikan, sehingga dalam mengerjakan studinya pun menjadi bermalas-malasan karena kurangnya perhatian dan motivasi terhadap anak.

Saat ini jumlah mahasiswa di Indonesia Telah mencapai 4,8 juta orang yaitu terhitung antara usia 19-24 tahun. Dan menurut laporan Data Base Kopertis Wilayah-I Medan tahun 2011 yang dapat diakses melalui http://sumut.bps.go.id, di Sumatera Utara ada sekitar 1.980 .475 orang mahasiswa.

Universitas Negeri Medan (Unimed) merupakan salah satu kampus yang ada di Sumatera Utara. Unimed memiliki mahasiswa yang 
kebanyakan berasal dari luar daerah Kota Medan. Berdasarkan data yang penulis terima dari pihak Badan Administrasi Kemahasiswaan (BAK) Unimed, dari 19.091 mahasiswa (Data Tahun 2011), kebanyakan mahasiswa Unimed tersebut berasal dari luar daerah kota Medan. Hal tersebut dipertegas lagi oleh pendapat salah seorang pegawai Badan Administrasi Kemahsiswaan (BAK) Unimed yang mengurusi seluruh biodata mahasiswa Unimed yaitu Bapak Akmal Gumarang. Ia mengatakan bahwa perbandingan jumlah persentase antara mahasiswa yang berasal dari luar daerah kota Medan dengan mahasiswa yang berasal dari dalam kota Medan adalah sekitar $72 \%$ dan $28 \%$. Sehingga banyak mahasiswa khususnya meraka yang berasal dari luar Kota Medan harus indekos untuk dapat mengikuti perkuliahan di kampus. Unimed Memiliki beberapa jurusan di dalamnya, yang salah satunya adalah Jurusan Pendidikan luar Sekolah (PLS). Jurusan Pendidikan Luar Sekolah (PLS) merupakan salah satu jurusan yang ada di Unimed, tepatnya berada di Fakultas Ilmu Pendidikan (FIP). Sama seperti jurusan yang lainnya, Mahasiswa jurusan PLS terdiri dari mahasiswa yang berasal dari luar daerah kota Medan, dan sebahagian lagi ada juga yang berasal dari Kota Medan.

Mahasiswa yang berasal dari luar Kota Medan pada umumnya mereka memilih untuk indekos agar bisa lebih dekat ke kampus, dan mahasiswa yang berasal dari Kota Medan pada umumnya mereka tidak perlu indekos, tapi mereka memilih untuk tinggal bersama orang tua mereka masing-masing.

Banyak dari antara mahasiswa ternyata gagal menyelesaikan pendidikannya dalam batas waktu minimal yang telah diprogramkan, atau bahkan gagal sama sekali menyelesaikan studinya. Faktor yang memungkinkan terjadinya kegagalan menyelesaikan studi di perguruan tinggi ini diantaranya adalah latar belakang mahasiswa, termasuk faktorfaktor dalam diri individu, karakteristik mahasiswa yang bersangkutan, serta motivasi yang ada.

\section{METODE}

Jenis penelitian yang digunakan dalam penelitian ini adalah jenis penelitian kuantitatif. Penulis ingin menggambarkan tentang Bagaimana hubungan motivasi belajar mahasiswa yang indekos dan yang tinggal bersama orang tua terhadap hasil belajar pada mahasiswa Unimed Fakultas Ilmu Pendidikan Jurusan Pendidikan Luar Sekolah Stambuk 2010.

Populasi dalam penelitian ini adalah mahasiswa Unimed Fakultas Ilmu Pendidikan Jurusan Pendidikan Luar Sekolah Stambuk 2010 yang berjumlah 33 mahasiswa reguler dan 23 mahasiswa ekstensi. Jadi jumlah keseluruhan populasi adalah 56 mahasiswa, yang terdiri atas 9 mahasiswa yang tinggal bersama orang tua dan 47 mahasiswa yang indekos. Apabila seseorang ingin meneliti semua elemen yang ada dalam wilayah penelitian, maka penelitiannya merupakan penelitian populasi. Jadi sampel dalam penelitian adalah semua mahasiswa Pendidikan Luar Sekolah (PLS) Stambuk 2010, yang berjumlah 56 orang mahasiswa, dan terdiri atas 9 Mahasiswa yang tinggal bersama orang tua dan 47 orang mahasiswa yang indekos. Untuk lebih jelasnya, dapat dilihat pada Tabel 3.1, yaitu tabel tentang data responden yang diteliti.

\section{PEMBAHASAN}

Berdasarkan hasil penelitian ini diketahui bahwa terdapat perbedaan motivasi belajar antara mahasiswa yang indekos dengan mahasiswa yang tinggal 
bersama orang tua, yang dalam hal ini penelitian dilakukan pada Mahasiswa Pendidikan Luar Sekolah Stambuk 2010 Fakultas Ilmu Pendidikan Universitas Negeri Medan.

Dari hasil pengolahan data yang telah dilakukan, ditemukan bahwa Mahasiswa Pendidikan Luar Sekolah memiliki motivasi belajar yang tinggi. Ini dapat dilihat dari sebagian besar mahasiswa Pendidikan Luar Sekolah Stambuk 2010 selalu memprioritaskan perkuliahan mereka dari pada hal-hal yang lain seperti oraganisasi, maupun pekerjaan. Tetapi apabila dibandingkan antara motivasi belajar mahasiswa yang indekos dengan mahasiswa yang tinggal bersama orang tua, maka mahasiswa yang tinggal bersama orang tua memiliki motivasi belajar yang lebih tinggi dibandingkan dengan motivasi belajar yang indekos.

Mahasiswa yang indekos dan jauh dari orang tua meruapakan mahasiswa yang telah dipercayakan oleh orang tua mereka untuk memimpin diri mereka masing-masing. Orang tua mereka telah memfasilitasi dan memberi kepercayaan penuh agar anaknya tersebut berhasil meraih gelar sarjana, dan kelak dapat membahagiakan orang tua mereka. Tetapi fasilitas yang diberikan oleh orang tua mereka belum cukup memadai untuk mendukung proses belajar mereka, ini dapat dilihat dari apabila mahasiswa memiliki kebutuhan yang mendesak, maka mahasiswa akan berkesulitan untuk memenuhinya, dan mereka harus hidup lebih mandiri lagi. Sedangkan mahasiswa yang tinggal bersama orang tua akan lebih ringan kehidupannya, dalam artian mahasiswa lebih mendapatkan perhatian dari keluarga, mahasiswa yang tinggal bersama orang tua tidak perlu khawatir jika membutuhkan biaya-biaya tak terduga dalam kegiatan belajarnya di perguruan tinggi. Hal ini mempengaruhi motivasi belajar mahasiswa, ketika mahasiswa mendapatkan perhatian keluarga yang lebih, maka motivasi belajarnyapun akan lebih kuat.

Hasil perhitungan motivasi belajar mahasiswa Pendidikan Luar Sekolah (PLS) Stambuk 2010 dikategorikan tinggi yaitu dengan nilai 2,87. Dan motivasi belajar mahasiswa yang indekos juga dikategorikan tinggi yaitu dengan nilai 2,85, sedangkan motivasi belajar mahasiswa yang tinggal bersama orang tua lebih tinggi lagi yaitu dengan nilai 2,94. Selanjutnya setelah dilakukan uji beda terhadap kedua kelompok data maka didapat nilai sebesar 0,416 yang artinya motivasi belajar antara mahasiswa Pendidikan Luar Sekolah (PLS) Stambuk 2010 yang indekos dan yang tinggal bersama orang tua berbeda dengan tingkat signifikansi yang agak rendah.

Jadi, sebenarnya kalau masih bisa tinggal bersama orang tua, dan itu tidak menghambat proses perkuliahan kita, itu akan lebih baik. Tetapi kalau pun memang harus indekos karena jauh dari orang tua, mahasiswa diharapkan dapat memilih tempat indekos yang baik dan yang mendukung mahasiswa dalam meningkatkan motivasi belajarnya.

Dari hasil penelitian ini, masih banyak kekurangan-kekurangan yang ada, dimana dalam pengambilan jumlah sampel antara mahasiswa yang indekos dengan jumlah sampel yang tinggal bersama orang tua memiliki perbedaan. Seharusnya dalam membandingkan dua kelompok data yang berbeda harus memiliki jumlah sampel yang sama.

\section{KESIMPULAN}

Berdasarkan hasil analisis data dan pengolahannya, maka penulis dapat menyimpulkannya sebagai berikut:

Motivasi belajar mahasiswa Pendidikan Luar Sekolah (PLS) stambuk 2010 secara umum dapat dikategorikan tinggi yaitu dengan nilai 2,87 .

Motivasi belajar mahasiswa Pendidikan Luar Sekolah (PLS) stambuk 2010 yang indekos dapat dikategorikan tinggi yaitu 
dengan nilai 2,85. Motivasi belajar mahasiswa Pendidikan Luar Sekolah (PLS) stambuk 2010 yang tinggal bersama oang tua juga dikategorikan tinggi yaitu dengan nilai 2,94. Terdapat perbedaan Motivasi belajar mahasiswa Pendidikan Luar Sekolah (PLS) stambuk 2010 yang indekos dengan Motivasi belajar mahasiswa Pendidikan Luar Sekolah (PLS) stambuk 2010 yang tinggal bersama oang tua dengan tingkat signifikansi sebesar 0,416 .

Apabila dibandingkan antara motivasi belajar mahasiswa Pendidikan Luar Sekolah (PLS) stambuk 2010 yang indekos dengan Motivasi belajar mahasiswa Pendidikan Luar Sekolah (PLS) stambuk 2010 yang tinggal bersama oang tua, maka Motivasi belajar mahasiswa Pendidikan Luar Sekolah (PLS) stambuk 2010 yang tinggal bersama oang tua masih lebih tinggi dibandingkan dengan Motivasi belajar mahasiswa Pendidikan Luar Sekolah (PLS) stambuk 2010 yang indekos.

\section{DAFTAR PUSTAKA}

Abdurrahman, Mulyono. 2003. Pendidikan Bagi Anak Berkesulitan Belajar. Jakarta: Rineka Cipta

Amir, M, Taufiq. 2009. Inovasi Pendidikan Melalui Problem Based Learning. Jakarta: Kencana Prenada Media Group.

A.M, Sardiman. 2007, Interaksi dan Motivasi Belajar Mengajar. Jakarta: Rajawali Pers.

Arikunto, Suharsimi. 2006. Prosedur Penelitian Suatu Pendekatan Praktik. Jakarta: Rineka Cipta.

Dimiyati, Mudjiono. 2006. Belajar dan Pembelajaran. Jakarta: Rineka Cipta.

Djaali. 2008. Psikologi Pendidikan. J akarta: Bumi Aksara.

Djaali, Muljono Pudji. 2008. Pengukuran dalam Bidang Pendidikan. Jakarta: Grasindo.
Nainggolan, E., \& Irwan, M. (2018). Identification of Non-Education Tutors Difficulty In Education Process Of Learning Study Groups. Journal of Nonformal Education, 4(2), 161-168.

Jareonsettasin, Teerakiat. 2002. Menjadi Orang Tua yang Baik. Jakarta: Yayasan Sri Satya Sai Indonesia.

Lumban, Gaol, N.T. 2011. Beberapa Faktor yang Berhubungan dengan Keberhasilan PKBM (Pusat Kegiatan Belajar Masyarakat) di Kota Medan. Skripsi tidak dipublikasikan. Universitas Negeri Medan.

Marzuki, M.S. 2010. Pendididikan Non Formal Dimensi Dalam Keaksaraan Fungsional, Pelatihan, dan Andragogi. Bandung: Remaja Rosdakarya.

Petersen, Lindy. 2008. Bagaimana Memotivasi Anak Belajar. Jakarta: Grasindo.

Purwanto, 2009. Evaluasi Hasil Belajar. Yogyakarta: Pustaka Pelajar

Purwanto, Ngalim. 2002. Ilmu Pendidikan Teoritis dan Praktis. Bandung: Remaja Rosdakarya

Sinaga, Benni, dkk. 2012. Goresan Anak Negeri Jeritan Pendidikan. Medan: Mitra

Slameto. 2010. Belajar dan Faktor-Faktor yang Mempengaruhinya. Jakarta: Rineka Cipta.

Sugiyono. 2009. Metode Penelitian Pendidikan (Pendekatan Kuantitatif, Kualitatif dan $R \& D)$. Bandung: Alfabeta.

Uno, B, Hamzah. 2010. Teori Motivasi dan Pengukurannya. Jakarta: Bumi Aksara.

Usman. Akbar. 2003. Pengantar Statistik. Jakarta: Bumi Aksara.

Zuriah, Nurul. 2005. Metodologi Penelitian Sosial dan Pendidikan (Teori-Aplikasi). Jakarta: Bumi Aksara. 